\title{
Simulation-based medical education to improve intrinsic motivation in medical students
}

\section{Helen-Cara Younan}

Faculty of Medicine, Imperial College London, London, UK
Correspondence: Helen-Cara Younan Faculty of Medicine, Imperial College London, Sir Alexander Fleming Building, Prince Consort Road, Kensington SW7 2BB, London, UK Tel +4477 78590724

Email helen-cara.younan12@imperial.ac.uk
This article was published in the following Dove Press journal:

Advances in Medical Education and Practice

28 December 2016

Number of times this article has been viewed

\section{Dear editor}

I read with great interest the results of the study by Deane and Murphy ${ }^{1}$ regarding learning strategies of medical students in a clinical rotation of obstetrics and gynecology.

Of particular interest was the finding that "obtaining a good examination result was the most significant reason why the attachment was important to students." The authors concluded that medical educators should consider strategies that foster more intrinsic drivers of student learning and more student-oriented learning resources and activities.

As a medical student in my penultimate year, I agree that intrinsic drivers can be more powerful motivators for learning, and these intrinsic drivers can help sustain students through a medical degree.

I propose that simulation-based training for medical students is a student-oriented activity that could be a method of increasing intrinsic drivers. Simulation-based medical education (SBME) involves learners in life-like experiences designed to imitate true clinical encounters. The benefits of simulation include enhanced opportunities for feedback, deliberate practice, measurement of outcomes, the ability to ensure uniform exposure to a variety of clinical presentations and provision of a controlled environment while mitigating the risks associated with learning in real patients. ${ }^{2}$

A meta-analysis by McGaghie et $\mathrm{al}^{3}$ found that SBME is superior to traditional clinical medical education in achieving specific clinical skill acquisition goals. Looking specifically at an obstetric and gynecology setting, a prospective study by Daniels et $\mathrm{al}^{4}$ found that simulation-trained teams had superior performance scores when tested in a labor and delivery drill. It is important to note, however, that these studies were in a postgraduate setting.

\section{How could SBME improve intrinsic drivers of motivation?}

In my recent obstetrics and gynecology placement, I participated in a simulation session with an actress and plastic models in which teams of students had to manage the delivery of a breach baby on an aeroplane, shoulder dystocia in a car park and an eclamptic fit in an elevator.

Reflecting on this session increased my intrinsic drive by motivating me to increase my clinical skills and knowledge so that I could be helpful if I ever found myself in any of these situations. 
Additionally, working with other students to deal with these situations also gave me an opportunity to practice important communication skills and teamwork. The session was enjoyed by all of the medical students in keeping with Birch et al, ${ }^{5}$ who found that SBME was enjoyed more than lecture-based teaching.

\section{What are the problems with SBME?}

SBME is expensive and requires more resources than traditional teaching methods. Certain equipment may be necessary, and an experienced teacher is needed to offer feedback to all participators.

The majority of research on the use of SBME has been in a postgraduate setting; however, research on its use in medical students is proving positive, and it is likely that benefits found in postgraduates can be generalized to all learners.

\section{Conclusion}

From my experiences, at the very least, SBME is an enjoyable and successful learning tool. Further research into its use in undergraduate medical education is needed, specifically regarding its ability to improve intrinsic motivation.

\section{Disclosure}

The author reports no conflicts of interest in this communication.

\section{References}

1. Deane RP, Murphy DJ. Proposed learning strategies of medical students in a clinical rotation in obstetrics and gynecology: a descriptive study. Adv Med Educ Pract. 2016;7:489-496.

2. Dudas RA, Colbert-Getz JM, Balighian E, et al. Evaluation of a simulation-based pediatric clinical skills curriculum for medical students. Simul Healthc. 2014;9(1):21-32.

3. McGaghie WC, Issenberg SB, Cohen ER, Barsuk JH, Wayne DB. Does simulation-based medical education with deliberate practice yield better results than traditional clinical education? A meta-analytic comparative review of the evidence. Acad Med. 2011;86(6):706-711.

4. Daniels K, Arafeh J, Clark A, Waller S, Druzin M, Chueh J. Prospective randomized trial of simulation versus didactic teaching for obstetrical emergencies. Simul Healthc. 2010;5(1):40-45.

5. Birch L, Jones N, Doyle P, et al. Obstetric skills drills: Evaluation of teaching methods. Nurse Educ Today. 2007;27(8):915-922.

Dove Medical Press encourages responsible, free and frank academic debate. The content of the Advances in Medical Education and Practice 'letters to the editor' section does not necessarily represent the views of Dove Medical Press, its officers, agents, employees, related entities or the Advances in Medical Education and Practice editors. While all reasonable steps have been taken to confirm the content of each letter, Dove Medical Press accepts no liability in respect of the content of any letter, nor is it responsible for the content and accuracy of any letter to the editor.

\section{Publish your work in this journal}

Advances in Medical Education and Practice is an international, peerreviewed, open access journal that aims to present and publish research on Medical Education covering medical, dental, nursing and allied health care professional education. The journal covers undergraduate education, postgraduate training and continuing medical education including emerging trends and innovative models linking education, research, and health care services. The manuscript management system is completely online and includes a very quick and fair peer-review system. Visit http://www.dovepress.com/testimonials.php to read real quotes from published authors. 